sensitivity to interactions depending only on the substrate and not on the substituents

(47) (a) R. G. Pews, Y. Tsuno, and R. W. Taft, J. Am. Chem. Soc., 89, 239 (1967); (b) S. K. Dayal, S. Ehrenson, and R. W. Taft, ibid., 94, 9113 (1972), (c) J. Fukunaga and R. W. Taft, J. Am. Chem. Soc., 97, $1612(1975)$.

(48) (a) P. J. Mitchell and L. Phillips, J. Chem. Soc., Perkin Trans. 2, 109 (1974); (b) I. R. Ager, L. Phillips, and S. J. Roberts, ibid., 1988 (1972)

(49) F. Membrey and J. P. Doucet. C. R. Hebd. Seances Acad. Sci., Ser C, 262 $149(1976)$.

(50) (a) A. Streitwleser, "Molecular Orbital Theory for Organic Chemists", Wiley,
New York, N.Y, 1961, chapter 2: (b) M. J. S. Dewar. "The Molecular Orbital Theory of Organic Chemistry", McGraw-Hill, New York, N.Y., 1969, chapter 6.

(51) J. N. Murrell, "The Theory of the Electronic Spectra of Organic Molecules", Methuen, London, 1963, chapters 9 and 10.

(52) For all figures, the numbers refer to the following substituents: $1, \mathrm{H}, \mathrm{H} ; 2$ $\mathrm{H}, \mathrm{NO}_{2} ; 3, \mathrm{H}_{1} \mathrm{CF}_{3} ; 4, \mathrm{H}, \mathrm{CH}_{3} ; 5, \mathrm{H}, \mathrm{OCH}_{3} ; 6, \mathrm{H}, \mathrm{F} ; 7, \mathrm{H}, \mathrm{Cl} ; 8, \mathrm{H}, \mathrm{Br} ; 9$ $\mathrm{CH}_{3} \mathrm{CH}_{10} \mathrm{CH}_{3}, 11, \mathrm{CH}_{3} \mathrm{OCH}, 12, \mathrm{CH}_{3}$ $\mathrm{OCH}_{3}, \mathrm{NO}_{2}, 15, \mathrm{NO}_{2}, \mathrm{NO} ; 10, \mathrm{CF}_{3} \mathrm{CF}_{3}, 17, \mathrm{Cl}_{3} ; 1, \mathrm{OCH}_{3}, \mathrm{CF}_{3} ; 14$ Cl.

\title{
1-Phenylallyl Cations and Their Rearrangement to Indanyl Cations in Superacidic Media ${ }^{\text {la }}$
}

\author{
George A. Olah, ${ }^{*}$ Gregorio Asensio, ${ }^{1 \mathrm{~b}}$ and Herbert Mayr ${ }^{1 \mathrm{~b}, \mathrm{c}}$
}

Hydrocarbon Institute, Department of Chemistry, University of Southern California, Los Angeles, California 90007 , and the Department of Chemistry, Case Western Reserve University, Cleveland, Ohio 44106

Received July 25, 1977

The 2-phenyl-2-penten-4-yl cation (4) has been prepared in magic acid solution at $-120^{\circ} \mathrm{C}$ from 2-phenyl-3-penten-2-01. Upon raising the temperature, a cyclic ion 12 was observed at $-80^{\circ} \mathrm{C}$, which finally rearranged to the indanyl cation 14 at $-70^{\circ} \mathrm{C}$. Methyl and deuterium substitution of the phenyl ring allowed identification of the structure of the intermediate ions and determination of the mechanism of the cyclization process.

A large number of stable alkyl-substituted allyl cations have been prepared and investigated ${ }^{2}$ in superacidic media, but very few phenylallyl cations ${ }^{3}$ are known as stable species at low temperature. At first glance this seems to be surprising since phenyl groups in most other carbocations have been shown to exhibit a greater stabilizing ability than alkyl groups. ${ }^{4}$ However, in contrast to alkylated allyl cations, phenylallyl cations can easily undergo intramolecular cyclization to the corresponding indanyl cations, which explains the difficulty in obtaining them as stable species. ${ }^{3 a, b}$

While ions 1,2 , and 3 were reported to be observable from -50 to $-70^{\circ} \mathrm{C}$ in $\mathrm{FSO}_{3} \mathrm{H}-\mathrm{SO}_{2}$ or $\mathrm{SO}_{2} \mathrm{ClF}, 4$ could not be de-<smiles>[R]C=C([R])[R]</smiles>

1. $\mathrm{R}_{1}=\mathrm{CH}_{3} ; \mathrm{R}_{2}=\mathrm{R}_{3}=\mathrm{Ph}$

2, $R_{1}=R_{2}=R_{3}=P h$

3, $\mathrm{R}_{1}=\mathrm{H} ; \mathrm{R}_{2}=\mathrm{Ph} ; \mathrm{R}_{3}=\mathrm{CH}_{3}$

$4, \mathrm{R}_{1}=\mathrm{R}_{3}=\mathrm{CH}_{3} ; \mathrm{R}_{2}=\mathrm{Ph}$

tected under these conditions since it rearranged to 14 (Scheme I). A deprotonation-reprotonation sequence was suggested to cause this rearrangement. ${ }^{3 \mathrm{~b}}$ Since deprotonation should be less favored in more acidic media, phenylallyl cations are expected to be more stable in $\mathrm{FSO}_{3} \mathrm{H}-\mathrm{SbF}_{5}-\mathrm{SO}_{2} \mathrm{ClF}$ than in $\mathrm{FSO}_{3} \mathrm{H}-\mathrm{SO}_{2}$. Therefore, we attempted to prepare 4 in magic acid solution and to study its rearrangement under these conditions.

\section{Results and Discussion}

When a precooled solution of 2-phenyl-3-penten-2-o1 (5) in $\mathrm{SO}_{2} \mathrm{ClF}$ was slowly added with good stirring to an excess of $\mathrm{FSO}_{3} \mathrm{H}-\mathrm{SbF}_{5}$ in $\mathrm{SO}_{2} \mathrm{ClF}$ at $-120^{\circ} \mathrm{C}$, the 2-phenylpentenyl cation 4 was obtained. It is stable below $-90^{\circ} \mathrm{C}$ but starts to rearrange at this temperature (Scheme I). Ion 4 was characterized by its ${ }^{1} \mathrm{H}$ NMR and ${ }^{13} \mathrm{C}$ NMR spectra (Tables I and II). Conversion of 4 into another ion was observed at $-80^{\circ} \mathrm{C}$. This species, however, could not be obtained with complete purity since contamination resulting from rearrangement to the known indanyl cation 14 began to occur at $-70^{\circ} \mathrm{C}$. Both

* Address correspondence to this author at the University of Southern California.

Scheme I<smiles>[R]c1cccc(C(C)(O)C=CC)c1</smiles>

$5, \mathrm{R}=\mathrm{H}$

$6, \mathrm{R}=\mathrm{CH}_{3}$

$17, \mathrm{R}=\mathrm{D}$
$4, \mathrm{R}=\mathrm{H}$

$7, \mathrm{R}=\mathrm{CH}_{3}$ $18, R=D$<smiles>[R]C1=C[C+]2C(C)=CC(C)(C)C2C=C1</smiles>

$8, \mathrm{R}=\mathrm{H}$

9, $\mathrm{R}=\mathrm{CH}_{3}$

19, $\mathrm{R}=\mathrm{D}$<smiles>[R]C1=CC=C2C(C)=CC(C)=C2C1</smiles>

$10, \mathrm{R}=\mathrm{H}$

11, $\mathrm{R}=\mathrm{CH}_{3}$

25, $R=D$<smiles>[R]c1ccc2c(c1)C(C)CC2(C)C</smiles>

$14, \mathrm{R}=\mathrm{H}$

$15, \mathrm{R}=\mathrm{CH}_{3}$

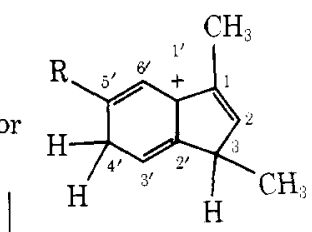

$12, \mathrm{R}=\mathrm{H}$

$13, \mathrm{R}=\mathrm{CH}$

$24, R=D$<smiles>CC1=C2CC=CC2C=CC1C</smiles>

16 
Table I. ${ }^{1}$ H NMR Chemical Shifts $(\delta)$ and Multiplicities of Phenylallyl Cations and Their Rearrangement Products

\begin{tabular}{|c|c|c|c|c|c|c|c|c|}
\hline Registry no. & Compd & $\mathrm{H}(2)$ & $\mathrm{H}(3)$ & $\mathrm{H}\left(3^{\prime}\right)$ & $\mathrm{H}\left(4^{\prime}\right)$ & $\mathrm{H}\left(5^{\prime}\right)$ & $\mathrm{H}\left(6^{\prime}\right)$ & Methyl substituents \\
\hline $64999-96-8$ & 4 & \multicolumn{6}{|c|}{$\begin{array}{c}\text { Aromatic and olefinic protons absorb in } \\
\text { a multiplet at } 8.3-9.3\end{array}$} & $\mathrm{C}(1)-\mathrm{CH}_{3} 3.6, \mathrm{C}(3)-\mathrm{CH}_{3} 3.0(\mathrm{~d})$ \\
\hline $65027-47-6$ & 12 & 8.6 & 4.3 & 8.6 & 4.7 & 8.9 & $8.2(\mathrm{~d})$ & $\mathrm{C}(1)-\mathrm{CH}_{3} 2.7, \mathrm{C}(3)-\mathrm{CH}_{3} 1.9(\mathrm{~d})$ \\
\hline 6503 & 13 & 8. & & 8. & 4.6 & 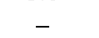 & & $\mathrm{C}(1)-\mathrm{CH}_{3} 2,6, \mathrm{C}(3)-\mathrm{CH}_{3} 1.7$ (d), $\mathrm{C}\left(5^{\prime}\right)-\mathrm{CH}_{3} 3.0$ \\
\hline 649 & 14 & 4. & 3.' & 8. & 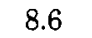 & 8.0 & & $\mathrm{C}(1)-\mathrm{CH}_{3} 3.5, \mathrm{C}(3)-\mathrm{CH}_{3} 1.7$ (d) \\
\hline $64999-58-2$ & 15 & 4.2 & 3.8 & 8.0 & 8.4 & - & $8.3(\mathrm{~s})$ & $\mathrm{C}(1)-\mathrm{CH}_{3} 3.7, \mathrm{C}(3)-\mathrm{CH}_{3} 1.8(\mathrm{~d}), \mathrm{C}\left(5^{\prime}\right)-\mathrm{CH}_{3} 2.6$ \\
\hline
\end{tabular}

Table II. ${ }^{13} \mathrm{C}$ NMR Chemical Shifts (ppm Downfield of $\mathrm{Me}_{4} \mathrm{Si}$ ) and Multiplicities of Phenylallyl Cations and Their Rearrangement Products

\begin{tabular}{|c|c|c|c|c|c|c|c|c|c|c|}
\hline & $C(1)$ & $\mathrm{C}(2)$ & $\mathrm{C}(3)$ & $\mathrm{C}\left(1^{\prime}\right)$ & $\mathrm{C}\left(2^{\prime}\right)$ & $\mathrm{C}\left(3^{\prime}\right)$ & $\mathrm{C}\left(4^{\prime}\right)$ & $\mathrm{C}\left(5^{\prime}\right)$ & $\mathrm{C}\left(6^{\prime}\right)$ & Methyl substituents \\
\hline 4 & $213.7(\mathrm{~s})$ & $136.3(\mathrm{~d})$ & $190.8(d)$ & $137.8(\mathrm{~s})$ & $\begin{array}{l}135.6 \\
(d)^{a}\end{array}$ & $131.0(\mathrm{~d})$ & $147.3(\mathrm{~d})$ & $131.0(\mathrm{~d})$ & $\begin{array}{l}131.6 \\
(d)^{a}\end{array}$ & $\mathrm{C}(1)-\mathrm{CH}_{3} 25.7,{ }^{a} \mathrm{C}(3)-\mathrm{CH}_{3} 21.6^{a}$ \\
\hline 12 & $\begin{array}{l}152.9 \\
(\mathrm{~s})^{a}\end{array}$ & $181.1(\mathrm{~d})^{a}$ & $46.0(\mathrm{~d})$ & $187.4(\mathrm{~s})$ & $\begin{array}{l}146.4 \\
(\mathrm{~s})^{a}\end{array}$ & $\begin{array}{l}158.1 \\
(d)^{a}\end{array}$ & $42.5(\mathrm{t})$ & $\begin{array}{l}171.5 \\
(\mathrm{~d})^{a}\end{array}$ & $126.4(\mathrm{~d})$ & $\mathrm{C}(1)-\mathrm{CH}_{3} 12.4,{ }^{a} \mathrm{C}(3)-\mathrm{CH}_{3} 11.1^{a}$ \\
\hline 13 & $\begin{array}{l}150.7 \\
(\mathrm{~s})^{a}\end{array}$ & $175.5(\mathrm{~d})^{a}$ & $45.1(\mathrm{~d})$ & $186.4(\mathrm{~s})$ & $\begin{array}{l}145.1 \\
(\mathrm{~s})^{a}\end{array}$ & $\begin{array}{l}154.3 \\
(d)^{\mathrm{a}}\end{array}$ & $45.6(t)$ & $191.8(\mathrm{~s})$ & $125.2(\mathrm{~d})$ & $\begin{array}{l}\mathrm{C}(1)-\mathrm{CH}_{3} 13.1,{ }^{a} \mathrm{C}(3)-\mathrm{CH}_{3} 11.2,{ }^{a} \\
\mathrm{C}\left(5^{\prime}\right)-\mathrm{CH}_{3} 25.4\end{array}$ \\
\hline 14 & $251.8(\mathrm{~s})$ & $56.5(t)$ & $41.9(\mathrm{~d})$ & $143.9(\mathrm{~s})$ & $184.4(\mathrm{~s})$ & $\begin{array}{l}132.0 \\
(d)^{a}\end{array}$ & $153.9(\mathrm{~d})$ & $\begin{array}{l}128.1 \\
(d)^{a}\end{array}$ & $\begin{array}{l}134.7 \\
(d)^{a}\end{array}$ & $\mathrm{C}(1)-\mathrm{CH}_{3} 24.4, \mathrm{C}(3)-\mathrm{CH}_{3} 16.9$ \\
\hline
\end{tabular}

a Relative assignment is uncertain.

isomerizations were irreversible, as demonstrated by recooling the samples to $-120^{\circ} \mathrm{C}$. The benzenium ion 8 , which might result from the electrocyclic ring closure of 4 , was eliminated as the intermediate observed at $-80^{\circ} \mathrm{C}$ on the basis of the ${ }^{13} \mathrm{C}$ NMR spectrum. This spectrum shows three vinylic singlets and four vinylic doublets, while the spectrum of 8 is expected to display two singlets and five doublets in the same region. Therefore, 10 and/or 12 are suggested as possible observable intermediates in the rearrangement sequence $4 \rightarrow 14$.

In order to differentiate between these two arenium ions, 2-( $m$-tolyl)-3-penten-2-ol (6) was treated with $\mathrm{FSO}_{3} \mathrm{H}_{-} \mathrm{SbF}_{5}$. Even at $-120^{\circ} \mathrm{C} 7$ could only be observed as a minor component in the spectrum of the cyclic intermediate. Rearrangement to the indanyl cation 15 occurred at $-60^{\circ} \mathrm{C}$. As expected for both 11 and 13, the ${ }^{13} \mathrm{C}$ NMR spectrum of the intermediate ion showed four olefinic singlets and three olefinic doublets.

Based on the ${ }^{1} \mathrm{H}$ NMR spectrum, the identification of 13 was possible. Since $H\left(6^{\prime}\right)$ of 13 is the only proton attached to an even numbered carbon in the heptatrienyl backbone, it should be the most shielded olefinic proton. For the same reason, $\mathrm{H}\left(4^{\prime}\right)$ should be the most shielded vinylic hydrogen in 11 . Figure $1 \mathrm{~b}$ clearly shows that the olefinic resonance at highest field is a singlet, in accord with $H\left(6^{\prime}\right)$ of 13 . On the contrary, $\mathrm{H}\left(4^{\prime}\right)$ of 11 should display a doublet.

Analogously, the high-field absorption of Figure la can be assigned to $H\left(6^{\prime}\right)$ of 12 , a doublet split by $H\left(5^{\prime}\right)$, whereas $H\left(4^{\prime}\right)$ of 10 should show a triplet. As observed previously with other benzenium ions,, 5 the methylene group of both 12 and $13 \mathrm{ab}$ sorbed as a broad singlet. Only trace amounts of 16 could be detected together with 12 , indicating that in the allyl cation $7 \mathrm{C}(3)$ attacks selectively at the $\mathrm{C}\left(2^{\prime}\right)$ position to yield the corresponding arenium ion $\mathbf{9}$.

Mechanism. As depicted in Scheme I, the electrocyclic ring closure of 4 and 7 to 8 and 9 is proposed to be the initial step. Further rearrangements by a series of two 1,2-hydride shifts yield 12 and 13, respectively. A deprotonation-reprotonation sequence cannot be accountable for the formation of 12 and 13 since this would imply protonation of indenes on the aromatic ring. This hypothesis, however, is in contrast to the observation that indanyl cations do not show deuterium incorporation in their six-membered rings when they are prepared from phenylallyl alcohols and $\mathrm{FSO}_{3} \mathrm{D} .{ }^{3}$ The observation that 7 cyclizes faster than 4 can be explained by the fact that

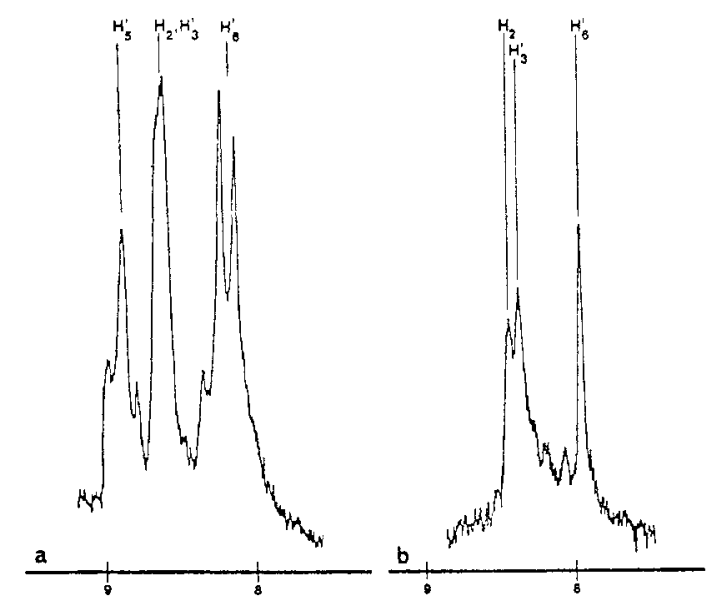

Figure 1. ${ }^{1} \mathrm{H}$ NMR spectra (olefinic protons) of (a) ion 12 and (b) ion 13 at $100 \mathrm{MHz}$.

the additional methyl group (R) stabilizes the allyl cation 7, where $R$ is attached to an uncharged carbon atom. The formation of 12 and 13 furthermore demonstrates that the 1,2hydride shifts are kinetically preferred over a 1,8-hydride shift, which would yield 14 and $\mathbf{1 5}$ directly from 8 and $\mathbf{9}$.

12 may be regarded as a benzenium ion with a vinyl substituent in the para position, whereas 10 is a benzenium ion with an 0 -vinyl group. It is well-known that alkylbenzenes yield $p$-alkylbenzenium ions when dissolved in strong acids. ${ }^{5}$ Therefore, we suggest that 12 can be observed as an intermediate because it is the thermodynamically most stable arenium ion.

Finally, the formation of 14 can proceed either via a series of intramolecular hydride shifts or via a deprotonation-reprotonation mechanism.

In order to prove the suggested reaction mechanism, we prepared, the meta-deuterated alcohol 17 and studied its ionization and further cyclization (Scheme II). Since secondary kinetic isotope effects are generally small, we expected 18 to yield equal amounts of 19 and 20 . At $-80^{\circ} \mathrm{C}$ these products then rearranged to the benzenium ions 24 and $21+$ 22, respectively. As expected for a mixture of these ions, the most shielded olefinic absorptions were a doublet $\left(\mathrm{H}\left(6^{\prime}\right)\right.$ of 21 and 22) and a singlet $\left(H\left(6^{\prime}\right)\right.$ of 24) centered at $\delta 8.2$. Since both 
Scheme II

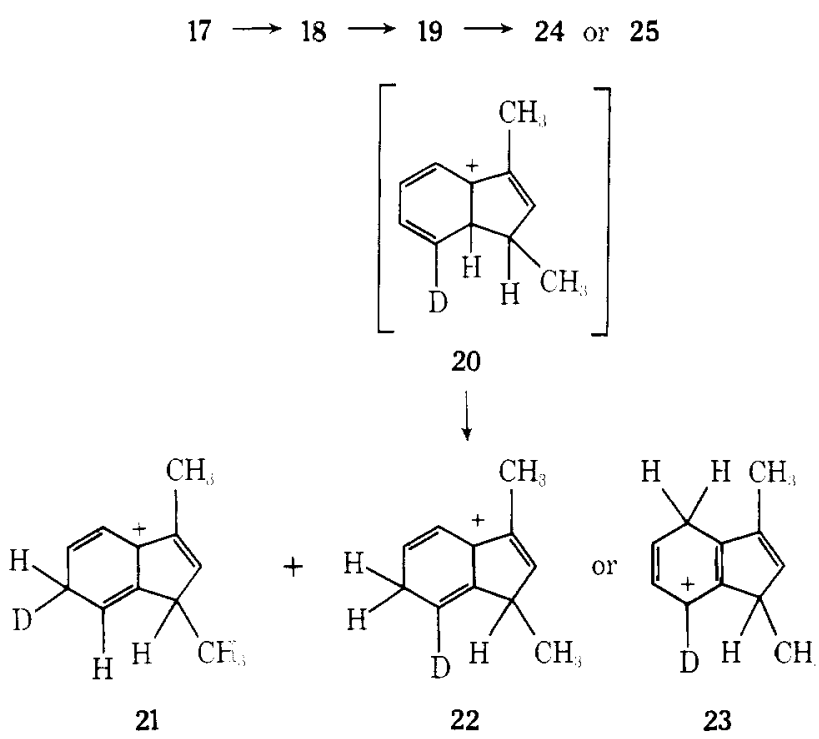

of the alternative structures, $\mathbf{2 3}$ and $\mathbf{2 5}$, should show doublets at $\delta 8.2$, the identity of the intermediates could be confirmed by this experiment.

However, the singlet (24) was of lower intensity than the doublet $(21+22)$, indicating a loss of deuterium from the $5^{\prime}$ position. Since a deprotonation-reprotonation mechanism was already excluded above, we suggest that in the cyclic intermediates (e.g., 24) slow 1,2-hydride migrations are taking place, yielding small equilibrium concentrations of isomeric benzenium ions. In this equilibration process deuterium can be washed out of the $5^{\prime}$ position to yield the observed spectrum.

The formation of 14 has already been observed by Pittman and Miller ${ }^{3 \mathrm{~b}}$ when 5 was treated with $\mathrm{FSO}_{3} \mathrm{H}$ at $-70^{\circ} \mathrm{C}$. Neither 4 nor 12 have been observed under these conditions. Therefore, we treated $\mathbf{5}$ with $\mathrm{FSO}_{3} \mathrm{H}-\mathrm{SO}_{2} \mathrm{ClF}$ at $-120^{\circ} \mathrm{C}$. In contrast to our observations in magic acid, the indanyl cation 14 was not formed, even at $-120^{\circ} \mathrm{C}$. Therefore, it is proposed that when magic acid is substituted for an acid of lower acidity another mechanism becomes operative. In such media an alternative route is deprotonation to a transient indene and a subsequent reprotonation, as proposed by Pittman and Miller. ${ }^{3 b}$

\section{Experimental Section}

Materials. Magic acid was prepared from triply distilled $\mathrm{FSO}_{3} \mathrm{H}$ and doubly distilled $\mathrm{SbF}_{5}$; a 1:1 molar ratio was used in all experiments. 2-Phenyl-3-penten-2-o1 (5) was commercially available (Chemical Samples Co.).

2-(m-Tolyl)-3-penten-2-ol (6) was prepared from $m$-methylacetophenone (Aldrich Chemical Co.) and 1-propenylmagnesium bromide (obtained from 1-bromo-1-propene, Chemical Samples $\mathrm{Co}$.) in THF: bp $104{ }^{\circ} \mathrm{C}(4 \mathrm{~mm}) ;{ }^{1} \mathrm{H} \mathrm{NMR}\left(\mathrm{CCl}_{4}\right) \delta 1.5(\mathrm{~d}, 3 \mathrm{H}, J=4 \mathrm{~Hz}$, $\left.\mathrm{CH}_{3}\right), 1.6\left(\mathrm{~s}, 3 \mathrm{H}, \mathrm{CH}_{3}\right), 5.5(\mathrm{~m}, 2 \mathrm{H}$, olefinic $\mathrm{CH}), 7.1(\mathrm{~m}, 4 \mathrm{H}$, phenyl $\mathrm{CH})$

2-( $m$-Deuteriophenyl)-3-penten-2-ol (17). $m$-Bromoacetophenone (Eastman) was converted into its ethylene ketal by refluxing and stirring with ethylene glycol and a small amount of $p$-toluenesulfonic acid in petroleum ether (bp $35-55^{\circ} \mathrm{C}$ ) for $36 \mathrm{~h}:{ }^{1} \mathrm{H}$ NMR $\left(\mathrm{CCl}_{4}\right) \delta 1.9\left(\mathrm{~s}, 3 \mathrm{H}, \mathrm{CH}_{3}\right), 4.1\left(\mathrm{~m}, 4 \mathrm{H}, \mathrm{CH}_{2}\right), 7.7(\mathrm{~m}, \mathrm{CH})$.

The ethylene ketal was treated with magnesium turnings in THF, and the Grignard compound was then hydrolyzed with $\mathrm{D}_{2} \mathrm{O}-\mathrm{D}_{2} \mathrm{SO}_{4}$ at room temperature to give $m$-deuterioacetophenone. Deuterium incorporation was ascertained by the observed $4: 3$ phenyl $\mathrm{CH} / \mathrm{CH}_{3}$ proton ratio, the substantial simplification of the ring proton absorption in the ${ }^{1} \mathrm{H}$ NMR spectrum, and the ${ }^{2} \mathrm{H}$ NMR spectrum (absorption at $\delta 7.6)$.

17 was prepared by reacting $m$-deuterioacetophenone with 1 -propenylmagnesium bromide in THF: bp $54-55^{\circ} \mathrm{C}(0.1 \mathrm{~mm}) ;{ }^{2} \mathrm{H}$ NMR (acetone) $\delta 7.6$ (relative to internal acetone- $d_{6}$ ).

Preparation of Ions. A dilute solution of the corresponding alcohol in $\mathrm{SO}_{2} \mathrm{ClF}$ at $-120^{\circ} \mathrm{C}$ was added dropwise with good stirring to an approximately 1:2 (by volume) solution of $\mathrm{FSO}_{3} \mathrm{H}-\mathrm{SbF}_{5}$ in $\mathrm{SO}_{2} \mathrm{ClF}$ at $-120^{\circ} \mathrm{C}$. The preparation of 4 and 18 required extremely slow addition to avoid further rearrangement due to local heating. Intermediate ions $12,21,22$, and 24 (observed at $-90^{\circ} \mathrm{C}$ ) were prepared by warming up the former solutions by a careful increase of the probe temperature in the ${ }^{1} \mathrm{H}$ NMR or ${ }^{13} \mathrm{C}$ NMR spectrometers, and they were stable up to $-80^{\circ} \mathrm{C}$. Ion 13 was observed in the original solution even at $-120^{\circ} \mathrm{C}$ and was stable up to $-70^{\circ} \mathrm{C}$. The spectra of indanyl cations 14 and 15 were recorded at $-60^{\circ} \mathrm{C}$.

Proton Magnetic Resonance Spectra. ${ }^{1} \mathrm{H}$ NMR spectra were obtained on a Varian Associates Model A56/60A or HA-100 spectrometer equipped with a variable-temperature probe. External $\mathrm{Me}_{4} \mathrm{Si}$ (capillary) was used as a reference for the carbenium ions and internal $\mathrm{Me}_{4} \mathrm{Si}$ for their precursors.

Carbon-13 Magnetic Resonance Spectra. The spectrometer used was a Varian Associates Model XL-100 equipped with a broad band decoupler and variable-temperature probe. Chemical shifts were measured from external (capillary) $\mathrm{Me}_{4} \mathrm{Si}$.

Acknowledgment. The support of our work by the National Science Foundation and the National Institutes of Health is gratefully acknowledged. We also thank the Program of Cultural Cooperation between the United States and Spain (G.A.) and the Deutsche Forschungsgemeinschaft (H.M.) for fellowships.

Registry No.-5, 4743-67-3; 6, 64999-97-9; 17, 64999-98-0; mdeuterioacetophenone, 64999-99-1; $m$-methylacetophenone, 585-74-0; 1-bromo-1-propene, 590-14-7.

\section{References and Notes}

(1) (a) Paper 211 of the Stable Carbocation Series. For Paper 210: G. A. Olah, G. Liang, P. Y. R. Schieyer, and P. Mison, J. Am. Chem. Soc., submitted for publication. (b) Postdoctoral Research Associate. (c) institüt für Organic Chemie, Universität Erlangen-Nürnberg, West Germany.

(2) N. C. Deno, Carbonium lons 1970, 2, Chapter $18(1970)$

(3) (a) N. Deno, C. U. Pitmann, Jr., and J. O. Turner, J. Am. Chem. Soc., 87, 2155 (1965); (b) C. U. Pittman and W. G. Miller, ibid., 95, 2947 (1973); (c) G. A. Olah and R. J. Spear. ibid., 97, 1539 (1975).

(4) G. A. Olah and P. W. Westerman, J. Am. Chem. Soc., 95, 7530 (1973).

(5) (a) G. A. Olah, J. S. Staral, G. Asensio, G. Liang, D. A. Forsyth, and G. D. Mateescu, J. Am. Chem. Soc., submitted for publication; (b) G. A. Olah, R, H. Schlosberg, R. D. Porter, Y. K. Mo, D. P. Kelly, and G. D. Mateescu, ibid., 94, 2034 (1972). 